\title{
Chemical Constituents of Biological Importance in the English Channel, November, 1930, to January, 1932. Part II. Hydrogen ion concentration, excess base, carbon dioxide, and oxygen.
}

By

L. H. N. Cooper, Ph.D., A.I.C.,

Assistant Chemist at the Plymouth Laboratory.

With 2 Figures in the Text.

\section{CONTENTS.}

I. Hydrogen Ion Concentration . . . . . . . . 729

II. Partial Pressure of Carbon Dioxide _ . . . . . . . 736

III. Total Carbon Dioxide . . . . . . . . . . . . . . 736

IV. Oxygen . . . . . . . . . . . . 738

V. Loss of Oxygen to the Atmosphere . . . . . . . 738

VI. Calculation of the Plankton Crop from the Chemical Data . . . 741

VII. Variation in Excess Base with Depth . . . . . . . 745

VIII. Methods . . . . . . . . . . . . . 749

Concentration of Hydrogen Ion . . . . . . . . . 749

Oxygen . . . . . . . . . . . 751

Excess Base . . . . . . . . . . . . . 751

IX. Summary . . . . . . . . . . . . 751

X. References . . . . . . . . . . 752

THE measurements of hydrogen ion concentration, excess base and oxygen described in this paper were carried out simultaneously with those of nutrient salts described in Part I. From these measurements, values for the partial pressure and total amount of carbon dioxide have been derived by methods described by Buch, Harvey, Wattenberg, and Gripenberg (1932).

\section{Hydrogen Ion Concentration.}

The method of determining $\mathrm{pH}$ and the correction to be applied to the measurements to give the $\mathrm{pH}$ at the temperature of collection, $\mathrm{pH}_{\mathrm{w}}$, or at a standard temperature of $12^{\circ}, \mathrm{pH}_{12^{\circ}}$, is given in the section on methods (p. 749). When the results are to be used for the calculation of total carbon dioxide or of any of the various functions concerned in the carbonate equilibrium in the sea, $\mathrm{pH}_{\mathrm{w}}$ is the more suitable quantity, since the interpolation tables of Buch et al. take account of temperature. For 
the calculation of partial pressure, $\mathrm{pH}_{\mathrm{w}}$ is essential. Values of $\mathrm{pH}_{\mathrm{w}}$ are given in Tables I to III. For comparison of $\mathrm{pH}$ values amongst themselves it is best to correct to a standard temperature, say, $12^{\circ}$.

Profiles of $\mathrm{pH}_{12}{ }^{\circ}$ for Stations L4 and El are given in Fig. 1. The minimum for the year was reached in January-February, 1931. At E1, $\mathrm{pH}_{12^{\circ}}$ increased steadily from mid-February until mid-summer. The effect of photosynthesis on the surface layers was most clearly shown in March.

The August gales not only led to vertical mixing and consequent levelling-up of $\mathrm{pH}$ values throughout the water column, but to a general lowering of $\mathrm{pH}$ due to absorption of carbon dioxide from the atmosphere. This effect of storms on $\mathrm{pH}$ has previously been observed by Atkins (1922, p. 763). The diatom outburst in September led to a slight increase in $\mathrm{pH}$. The results are in general agreement with the seasonal changes at E1 already found by Atkins (1922, '23, '24). He, however, applied the McClendon temperature coefficient which applies at constant $\mathrm{CO}_{2}$-tension and not at constant $\Sigma \mathrm{CO}_{2}$, and is of opposite sign to that of Buch. But since his measurements were commonly made within one or two degrees of $12^{\circ}$, the amount of the correction is small so that a general comparison may be made with the present set of results.

The seasonal change in $\mathrm{pH}$ at the surface at $\mathrm{El}$ is also plotted in Fig. 2. The differences between the curves for $\mathrm{pH}_{12}{ }^{\circ}$, and $\mathrm{pH}_{\mathrm{w}}$ is shown. By the definition of $\mathrm{pH}_{12^{\circ}}$, the two curves cross at $12^{\circ} \mathrm{C}$. The effect of increasing temperature, apart from other changes in the water, is seen on comparison of the two $\mathrm{pH}$ curves with the temperature curve between May 18th and July 10th.

The profiles for $\mathrm{L} 4$ are peculiar. $\mathrm{pH}_{12}{ }^{\circ}$ shows a tendency to be lower at the surface than at the bottom $(50 \mathrm{~m}$.) even during the spring period of plankton growth. Station L4 is shallower than E1 and more subject to river influence and vertical mixing is probably more effective. There will thus be more tendency for the surface water, depleted of carbon dioxide by photosynthesis, to re-absorb the gas from the atmosphere, whereas the $\mathrm{pH}$ of the bottom waters may be raised by mixing with the waters from around 20 metres. The values of $\mathrm{pH}_{\mathrm{w}}$ (Table I) show a tendency to approach $8 \cdot 15-8 \cdot 16$, the $\mathrm{pH}$ of sea-water in equilibrium with the air. The results for November 30th show that the effect may be confined to the surface five metres. On this date the surface salinity was reduced to $33 \cdot 6 \%$. The lower surface $\mathrm{pH}$ was particularly apparent after the very stormy period in mid-August. The phenomenon was observed on six occasions, and in most cases it was confirmed by redeterminations.

Similar lower surface values have been found in winter by Atkins (1922, p. 763). 

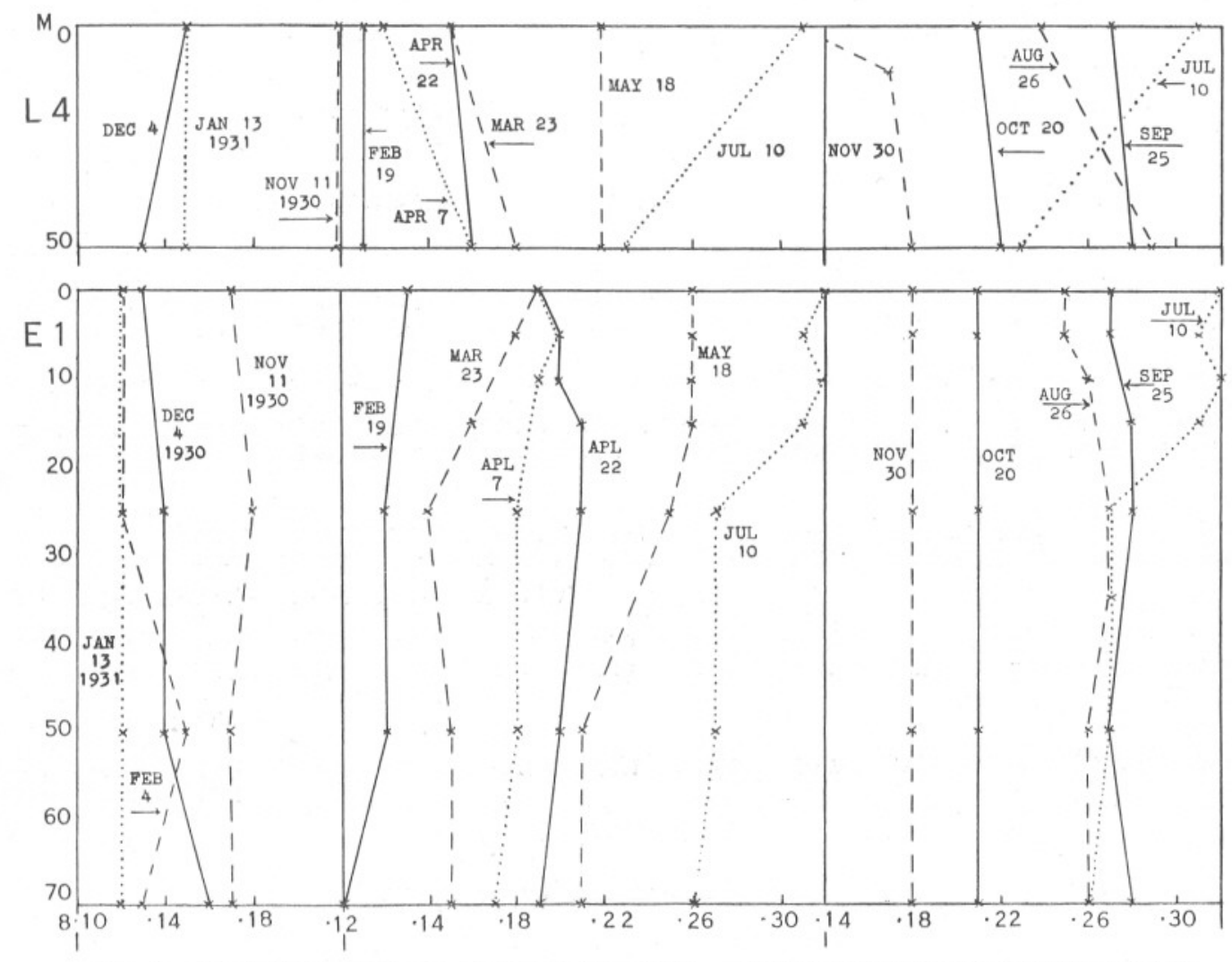

Fig. 1. $-\mathrm{pH}$ at Stations L4 and E1 corrected to $12^{\circ}$ C. The depth scale for L4 is half that for E1. 
TABLE I.

Station L4. Depth Series.

Date

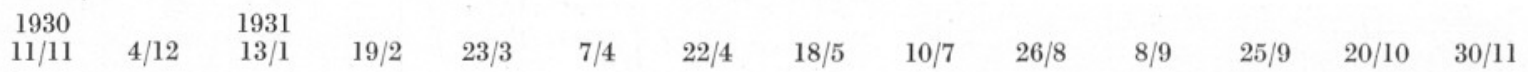

$\mathrm{pH}$ at temperature of collection $\left(\mathrm{pH}_{\mathrm{w}}\right)$.

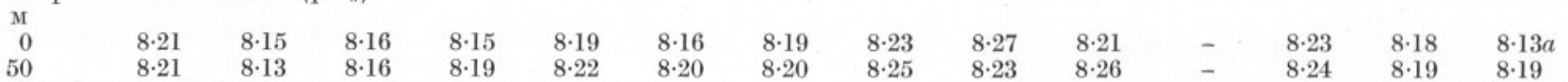

Excess BASE (by Wattenberg's Method, milli-equivalents per litre) (b).

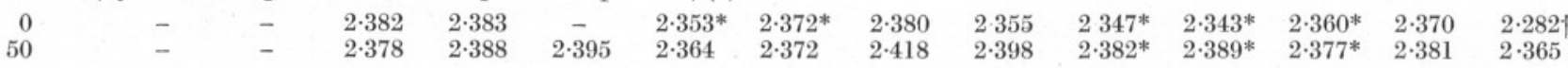

乏 $\mathrm{CO}_{2}$ (c.e. per litre at N.T.P.).

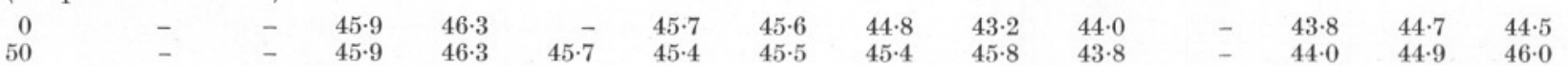

Partial Pressure of $\mathrm{CO}_{2}, \mathrm{rCO}_{2}$ (Atmospheres $\times 10^{-4}$ ),

\begin{tabular}{|c|c|c|c|c|c|c|c|c|c|c|c|c|c|c|}
\hline 0 & $2 \cdot 6$ & $3 \cdot 0$ & $2 \cdot 9$ & $3 \cdot 0$ & $2 \cdot 6$ & $2 \cdot 9$ & $2 \cdot 6$ & $2 \cdot 3$ & $2 \cdot 1$ & $2 \cdot 5$ & - & $2 \cdot 4$ & $2 \cdot 7$ & $3 \cdot 1$ \\
\hline 50 & $2 \cdot 6$ & $3 \cdot 1$ & 2.9 & $3 \cdot 0$ & $2 \cdot 4$ & $2 \cdot 5$ & $2 \cdot 5$ & $2 \cdot 2$ & $2 \cdot 4$ & $2 \cdot 2$ & - & $2 \cdot 4$ & $2 \cdot 7$ & $2 \cdot 6$ \\
\hline
\end{tabular}

Additional data and notes.

a, $5 \mathrm{~m} ., 8 \cdot 17$.

b, Station L6 ; $25 / 9,0$ m. $2 \cdot 367^{*} ; 62$ m. $2 \cdot 387^{*} ; 20 / 10,0$ m. $2 \cdot 370$; $67 \mathrm{~m} .2 \cdot 386^{*}$

$g$, From $\mathrm{pH}$ and salinity.

* Mean of duplicate analyses. $\quad \dagger$ Mean of quadruplicate analyses. 
TABLE II.
11/11
$4 / 2$
$19 / 2$
$23 / 3$
$7 / 4$
$22 / 4$
$18 / 5$
$10 / 7$
$26 / 8$
$8 / 9$
$25 / 9$
$20 / 10 \quad 30 / 11$

4/12

1931

$\mathrm{pH}$ at temperature of collection $\left(\mathrm{pH}_{\mathrm{w}}\right)$.

M
0
5
10
15
25
50
$68-71$

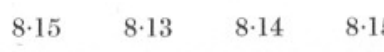

$15 \quad 8 \cdot 16$

$\begin{array}{llll}- & - & - & - \\ - & - & - & -\end{array}$

-
-
$-\overline{15}$

$8 \cdot 22$
$8 \cdot 21$
-

$8 \cdot 22$
$8 \cdot 23$
$8 \cdot 22$

$8 \cdot 22$
$8 \cdot 23$
$8 \cdot 23$
$8 \cdot 24$
$8 \cdot 24$
$8 \cdot 23$
$8 \cdot 22$

$8 \cdot 27$
$8 \cdot 27$
$8 \cdot 27$
$8 \cdot 27$
$8 \cdot 27$
$8 \cdot 24$
$8 \cdot 24$

$8 \cdot 28$

$$
8 \cdot 27
$$$$
\begin{aligned}
& 8 \cdot 28 \\
& 8 \cdot 28 \\
& 8 \cdot 28
\end{aligned}
$$$$
\begin{aligned}
& 8 \cdot 28 \\
& 8 \cdot 28 \\
& 8 \cdot 28
\end{aligned}
$$

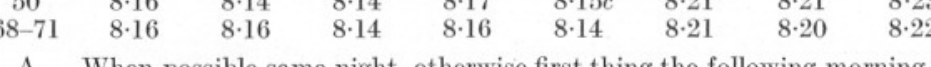

$8 \cdot 28$
$8 \cdot 27$

$\begin{array}{lcccc}8 \cdot 21 & - & 8 \cdot 23 & 8 \cdot 18 & 8 \cdot 17 \\ 8 \cdot 22 & - & 8 \cdot 23 & 8 \cdot 18 & 8 \cdot 17 \\ 8 \cdot 23 & - & - & - & - \\ - & - & 8 \cdot 24 & - & - \\ 8 \cdot 24 d & - & 8 \cdot 24 & 8 \cdot 18 & 8 \cdot 17 \\ 8 \cdot 23 & - & 8 \cdot 23 & 8 \cdot 18 & 8 \cdot 17 \\ 8.24 & & 8 \cdot 24 & 8 \cdot 18 & 8 \cdot 17\end{array}$

Excess BASE (Wattenberg's Method; milli-equivalents per litre).

$\begin{array}{clllllllllllllll}0 & - & - & 2 \cdot 377^{*} & - & 2 \cdot 388^{*} & 2 \cdot 384^{*} & 2 \cdot 380^{*} & 2 \cdot 382 & 2 \cdot 384^{*} & 2 \cdot 360 & 2 \cdot 365^{*} & 2 \cdot 357^{*} & 2 \cdot 370^{*} & 2 \cdot 375 & 2 \cdot 370^{*} \\ 5 & - & - & - & - & - & 2 \cdot 394^{*} & 2 \cdot 380 & 2 \cdot 395 & 2 \cdot 384 & 2 \cdot 355 & 2 \cdot 357 & 2 \cdot 379 & 2 \cdot 384 & 2 \cdot 370 & 2 \cdot 381 \\ 10 & - & - & - & - & - & 2 \cdot 384^{*} & - & 2 \cdot 391 & 2 \cdot 397 & 2 \cdot 355 & 2 \cdot 362 & 2 \cdot 379 h & - & - & - \\ 25 & - & - & 2 \cdot 384^{*} & - & 2 \cdot 394^{*} & 2 \cdot 394^{*} & 2 \cdot 384 & 2 \cdot 391 & 2 \cdot 390 & 2 \cdot 360 e & 2 \cdot 384 & 2 \cdot 379 & 2 \cdot 384 & 2 \cdot 372 & 2 \cdot 392 \\ 50 & - & - & 2 \cdot 380^{*} & - & 2 \cdot 388^{*} & 2 \cdot 400^{*} & 2 \cdot 370 & 2 \cdot 391 & 2 \cdot 395^{*} & 2 \cdot 364 & 2 \cdot 379 & 2 \cdot 382^{*} & 2 \cdot 384 & 2 \cdot 370 & 2 \cdot 384 \\ 50 & - & - & 2 \cdot 381^{*} & - & 2 \cdot 393^{*} & (2 \cdot 373) & 2 \cdot 384 & 2 \cdot 397^{*} & 2 \cdot 391^{*} & 2 \cdot 365^{*} & 2 \cdot 376 & 2 \cdot 411 & 2 \cdot 395 & 2 \cdot 375 & 2 \cdot 378 \\ 68-71 & - & - & 16 / 1 & - & 23 / 2 & 26 / 3 & 14 / 4 & 28 / 4 & 28 / 5 & 22 / 7 & 22 / 9 & 22 / 9 & 3 / 10 & 28 / 10 & 5 / 12\end{array}$

OXYGen (c.c. $\mathrm{O}_{2}$ per litre at N.T.P.).

\begin{tabular}{|c|c|c|c|c|c|c|c|c|c|c|c|c|c|c|c|}
\hline 0 & - & - & - & - & $6 \cdot 43$ & $6 \cdot 49^{*}$ & $6 \cdot 66^{*}$ & $6 \cdot 92^{*}$ & $6 \cdot 44^{*}$ & - & $5 \cdot 71^{*}$ & $5 \cdot 84$ & $5 \cdot 81 *$ & $5 \cdot 76^{*}$ & $5 \cdot 86^{*}$ \\
\hline 5 & - & - & - & - & - & $6 \cdot 48$ & $6 \cdot 68^{*}$ & $7 \cdot 00$ & $6 \cdot 40$ & - & $5 \cdot 67^{*}$ & $5 \cdot 80^{*}$ & $5 \cdot 74$ & $5 \cdot 71^{*}$ & $5 \cdot 81^{*}$ \\
\hline 10 & - & - & - & - & $6 \cdot 46$ & 648 & 658 & $7 \cdot 04$ & $6 \cdot 50^{\text {* }}$ & - & $5 \cdot 62 *$ & - & - & - & - \\
\hline 15 & - & - & - & - & - & - & $6 \cdot 66$ & - & $6 \cdot 55$ & - & $5 \cdot 58$ & - & $5 \cdot 75$ & - & - \\
\hline 25 & - & - & - & - & $6 \cdot 35$ & $5 \cdot 42 * ?$ & $6.56^{*}$ & $6.92 *$ & $6 \cdot 70^{*}$ & - & $5 \cdot 54^{*}$ & $5 \cdot 75$ & $5 \cdot 71^{*}$ & $5 \cdot 68^{*}$ & $5 \cdot 79^{*}$ \\
\hline 50 & - & - & - & -- & $6 \cdot 37^{*}$ & $6 \cdot 30$ & $6.58 *$ & $6 \cdot 75$ & $6 \cdot 54$ & - & $5 \cdot 52 *$ & $5 \cdot 62 *$ & $5 \cdot 66^{*}$ & $5 \cdot 68^{*}$ & $5 \cdot 79^{*}$ \\
\hline 60 & - & - & - & - & $6 \cdot 36$ & - & - & - & - & - & - & - & $5 \cdot 64$ & - & - \\
\hline $68-71$ & .. & - & - & - & $6.46^{*}$ & $6 \cdot 40^{*}$ & $6.51^{*}$ & $6 \cdot 81 *$ & $6 \cdot 61^{*}$ & - & $5 \cdot 47$ & $5 \cdot 38 *$ & $5 \cdot 64 *$ & $5 \cdot 64^{*}$ & $5 \cdot 78 *$ \\
\hline B & .. & - & - & -- & $19 / 2$ & $23 / 3$ & $7 / 4$ & $23 / 4$ & $18 / 5$ & - & $27 / 8$ & $8 / 9$ & $25 / 9$ & $20 / 10$ & $1 / 12$ \\
\hline
\end{tabular}


TABLE II-continued.

\begin{tabular}{|c|c|c|c|c|c|c|c|c|c|c|c|c|c|c|c|}
\hline \multirow[t]{2}{*}{ Date } & $\begin{array}{l}1930 \\
11 / 11\end{array}$ & $4 / 12$ & $\begin{array}{l}1931 \\
13 / 1\end{array}$ & $4 / 2$ & $19 / 2$ & $23 / 3$ & $7 / 4$ & $22 / 4$ & $18 / 5$ & $10 / 7$ & $26 / 8$ & $8 / 9$ & $25 / 9$ & $20 / 10$ & $30 / 11$ \\
\hline & \multicolumn{15}{|c|}{$\Sigma \mathrm{CO}_{2}$ (c.c. $\mathrm{CO}_{2}$ per litre at N.T.P.). } \\
\hline 0 & - & - & $46 \cdot 1$ & $\stackrel{9}{7}^{4} 4$ & $46 \cdot 1$ & $45 \cdot 4$ & $45 \cdot 2$ & $45 \cdot 4$ & $44 \cdot 3$ & $43 \cdot 0$ & $44 \cdot 1$ & - & $44 \cdot 0$ & $44 \cdot 7$ & $45 \cdot 2$ \\
\hline 5 & - & - & - & - & - & $45 \cdot 6$ & $45 \cdot 1$ & $45 \cdot 4$ & $44 \cdot 3$ & $43 \cdot 2$ & $44 \cdot 0$ & - & $44 \cdot 1$ & $44 \cdot 7$ & $45 \cdot 3$ \\
\hline 10 & - & - & - & - & - & - & $45 \cdot 2$ & $45 \cdot 3$ & $44 \cdot 3$ & $43 \cdot 1$ & $43 \cdot 9$ & - & - & - & - \\
\hline 15 & - & - & - & - & - & $45 \cdot 5$ & - & - & - & $43 \cdot 2$ & - & - & $44 \cdot 1$ & - & - \\
\hline 25 & - & - & $46 \cdot 1$ & $46 \cdot 4$ & $46 \cdot 4$ & $45 \cdot 8$ & $45 \cdot 4$ & $45 \cdot 2$ & $44 \cdot 6$ & $43 \cdot 6$ & $44 \cdot 1$ & - & $44 \cdot 1$ & $44 \cdot 7$ & $45 \cdot 5$ \\
\hline 50 & - & - & $46 \cdot 2$ & $46 \cdot 2$ & $46 \cdot 4$ & $45 \cdot 7$ & $45 \cdot 3$ & $45 \cdot 3$ & $45 \cdot 1$ & $43 \cdot 6$ & $44 \cdot 2$ & - & $44 \cdot 2$ & $44 \cdot 7$ & $45 \cdot 4$ \\
\hline \multirow[t]{2}{*}{$68-71$} & - & - & $46 \cdot 3$ & $46 \cdot 3$ & $46 \cdot 5$ & $45 \cdot 3(?)$ & $45 \cdot 6$ & $45 \cdot 6$ & $45 \cdot 0$ & $44 \cdot 0$ & $44 \cdot 2$ & - & $44 \cdot 2$ & $44 \cdot 7$ & $45 \cdot 3$ \\
\hline & \multicolumn{15}{|c|}{$\Sigma \mathrm{CO}_{2}+\mathrm{O}_{2}$ (c.e. per litre at N.T.P.). } \\
\hline 0 & - & - & - & - & $52 \cdot 5$ & $51 \cdot 9$ & $51 \cdot 9$ & $52 \cdot 3$ & $50 \cdot 7$ & - & $49 \cdot 8$ & - & $49 \cdot 8$ & $50 \cdot 4$ & $51 \cdot 1$ \\
\hline 5 & - & - & - & - & - & $52 \cdot 1$ & $51 \cdot 8$ & $52 \cdot 4$ & $50 \cdot 7$ & - & $49 \cdot 7$ & - & $49 \cdot 8$ & $50 \cdot 4$ & $51 \cdot 1$ \\
\hline 10 & - & - & - & - & - & - & $51 \cdot 8$ & $52 \cdot 3$ & $50 \cdot 8$ & - & $49 \cdot 5$ & - & - & - & - \\
\hline 15 & - & - & - & - & - & $52 \cdot 0$ & - & - & - & - & - & - & $49 \cdot 8$ & - & - \\
\hline 25 & - & - & - & - & $52 \cdot 7$ & $(51 \cdot 2)$ & $52 \cdot 0$ & $52 \cdot 1$ & $51 \cdot 3$ & - & $49 \cdot 6$ & - & $49 \cdot 8$ & $50 \cdot 4$ & $51 \cdot 3$ \\
\hline 50 & - & - & - & - & $52 \cdot 8$ & $52 \cdot 0$ & $51 \cdot 9$ & $52 \cdot 1$ & $51 \cdot 6$ & - & $49 \cdot 7$ & - & $49 \cdot 9$ & $50 \cdot 4$ & $51 \cdot 2$ \\
\hline \multirow[t]{2}{*}{$68-71$} & - & - & - & - & $53 \cdot 0$ & $(51 \cdot 7)$ & $52 \cdot 1$ & $52 \cdot 2$ & $51 \cdot 6$ & - & $49 \cdot 7$ & - & $49 \cdot 8$ & $50 \cdot 3$ & $51 \cdot 1$ \\
\hline & \multicolumn{15}{|c|}{ Partial Pressure of $\mathrm{CO}_{2}, \mathrm{PCO}_{2}$ (Atmosphere $\left.\times 10^{-4}\right)$. } \\
\hline 0 & $\begin{array}{r}3 \cdot 0 \\
0\end{array}$ & $\begin{array}{r}g \\
3 \cdot 1\end{array}$ & $3 \cdot 0$ & $\begin{array}{r}g \\
3 \cdot 0\end{array}$ & $2 \cdot 9$ & $2 \cdot 4$ & $2 \cdot 4$ & $2 \cdot 4$ & $2 \cdot 1$ & $2 \cdot 1$ & 2.5 & - & $2 \cdot 4$ & $2 \cdot 7$ & $2 \cdot 8$ \\
\hline 5 & - & - & - & - & - & $2 \cdot 4$ & $2 \cdot 3$ & $2 \cdot 3$ & $2 \cdot 1$ & $2 \cdot 1$ & $2 \cdot 5$ & - & $2 \cdot 4$ & $2 \cdot 7$ & $2 \cdot 8$ \\
\hline 10 & - & - & - & - & - & - & $2 \cdot 4$ & $2 \cdot 3$ & $2 \cdot 1$ & $2 \cdot 1$ & $2 \cdot 4$ & - & - & - & - \\
\hline 15 & - & - & - & - & - & $2 \cdot 4$ & - & $2 \cdot 3$ & $2 \cdot 1$ & $2 \cdot 1$ & - & - & $2 \cdot 4$ & - & - \\
\hline 25 & $2 \cdot 9$ & $3 \cdot 0$ & $3 \cdot 0$ & $3 \cdot 0$ & $3 \cdot 0$ & $2 \cdot 5$ & $2 \cdot 4$ & $2 \cdot 3$ & $2 \cdot 1$ & $2 \cdot 1$ & $2 \cdot 4$ & - & $2 \cdot 4$ & $2 \cdot 7$ & $2 \cdot 8$ \\
\hline 50 & $2 \cdot 9$ & $3 \cdot 0$ & $3 \cdot 0$ & $2 \cdot 8$ & $3 \cdot 0$ & $2 \cdot 4$ & $2 \cdot 4$ & $2 \cdot 3$ & $2 \cdot 3$ & $2 \cdot 1$ & $2 \cdot 4$ & - & $2 \cdot 4$ & $2 \cdot 7$ & $2 \cdot 8$ \\
\hline & 2.9 & $2 \cdot 9$ & $3 \cdot 0$ & $3 \cdot 0$ & $3 \cdot 0$ & $2 \cdot 4$ & $2 \cdot 5$ & $2 \cdot 4$ & $2 \cdot 3$ & $2 \cdot 1$ & $2 \cdot 4$ & - & $2 \cdot 4$ & $2 \cdot 7$ & $2 \cdot 8$ \\
\hline
\end{tabular}

* Mean of duplicate analyses.

Additional data.

c. $60 \mathrm{~m} .8 \cdot 14$.

A. Date of analysis.

d. $35 \mathrm{~m} \cdot 8 \cdot 24$.

B. Reagents added when collected on board. Acidified and titrated same night or following day as shown.

g. From $\mathrm{pH}$ and salinity.

h. $15 \mathrm{~m} \cdot 2 \cdot 379$. 


\section{TABLE III}

\section{Station E2}

\begin{tabular}{|c|c|c|c|c|}
\hline \multirow[b]{2}{*}{ Date } & \multicolumn{4}{|c|}{$\begin{array}{c}\mathrm{pH} \text { at temperature of } \\
\text { collection }\left(\mathrm{pH}_{\mathrm{w}}\right) .\end{array}$} \\
\hline & $\begin{array}{l}1931 \\
4 / 2\end{array}$ & $22 / 4$ & $26 / 8$ & $30 / 11$ \\
\hline M & & & & \\
\hline 0 & $8 \cdot 17$ & $8 \cdot 19$ & $8 \cdot 22$ & $8 \cdot 17$ \\
\hline 5 & - & $8 \cdot 19$ & $8 \cdot 23$ & $8 \cdot 18$ \\
\hline 10 & - & $8 \cdot 20$ & $8 \cdot 23$ & - \\
\hline 25 & $8 \cdot 17$ & $8 \cdot 20$ & $8 \cdot 23 f$ & $8 \cdot 18$ \\
\hline 50 & - & $8 \cdot 21$ & 8.25 & $8 \cdot 18$ \\
\hline 70 & - & - & $8 \cdot 27$ & $8 \cdot 18$ \\
\hline $87-91$ & $8 \cdot 16$ & $8 \cdot 19$ & 8.25 & $8 \cdot 17$ \\
\hline
\end{tabular}

Excess Base

(milli-equivalents per litre).

$\Sigma \mathrm{CO}_{2}$$$
22 / 4 \quad 26 / 8 \quad 30 / 1
$$$$
\text { .er pitre at N.T.P.). }
$$

$\mathrm{PCO}_{2}$
$\left(\right.$ Atm. $\left.\times 10^{-4}\right)$.

\begin{tabular}{lllcccccccc} 
& \multicolumn{9}{c}{$g$} & \multicolumn{9}{c}{$g$} \\
$2 \cdot 381$ & $2 \cdot 368$ & $2 \cdot 374^{*}$ & $46 \cdot 0$ & $45 \cdot 5$ & $44 \cdot 0$ & $45 \cdot 2$ & $2 \cdot 8$ & $2 \cdot 6$ & $2 \cdot 4$ & $2 \cdot 8$ \\
$2 \cdot 381$ & $2 \cdot 373$ & $2 \cdot 389$ & - & $45 \cdot 5$ & $44 \cdot 0$ & $45 \cdot 4$ & - & $2 \cdot 6$ & $2 \cdot 4$ & $2 \cdot 7$ \\
$2 \cdot 376$ & $2 \cdot 397 *$ & - & - & $45 \cdot 3$ & $44 \cdot 5$ & - & - & $2 \cdot 5$ & $2 \cdot 4$ & - \\
$2 \cdot 376$ & $2 \cdot 378^{*}$ & $2 \cdot 392$ & $46 \cdot 0$ & $45 \cdot 3$ & $44 \cdot 2$ & $45 \cdot 4$ & $2 \cdot 8$ & $2 \cdot 5$ & $2 \cdot 4 f$ & $2 \cdot 7$ \\
$2 \cdot 386$ & $2 \cdot 394$ & $2 \cdot 392$ & - & $45 \cdot 4$ & $44 \cdot 4$ & $45 \cdot 4$ & - & $2 \cdot 4$ & $2 \cdot 3$ & $2 \cdot 7$ \\
- & $2 \cdot 379$ & $2 \cdot 381$ & - & - & $43 \cdot 9$ & $45 \cdot 3$ & - & - & $2 \cdot 2$ & $2 \cdot 7$ \\
$2 \cdot 404$ & $2 \cdot 384$ & $2 \cdot 384^{*}$ & $46 \cdot 1$ & $45 \cdot 9$ & $44 \cdot 3$ & $45 \cdot 4$ & $2 \cdot 9$ & $2 \cdot 5$ & $2 \cdot 3$ & $2 \cdot 8$
\end{tabular}

g. Calculated from $\mathrm{pH}$ and salinity. Additional data.

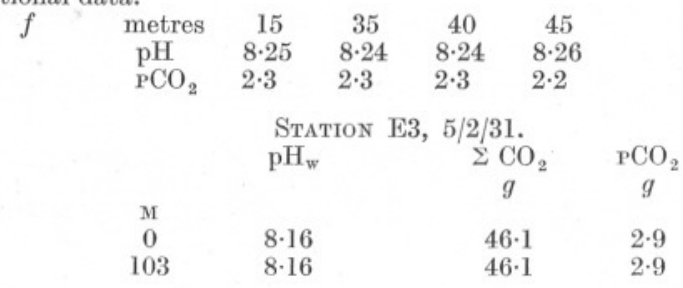




\section{Partial Pressure of Carbon Dioxide.}

The partial pressure and total amount of carbon dioxide (Tables I to III) have been found from $\mathrm{pH}_{\mathrm{w}}$, excess base and temperature by means of interpolation tables (Buch, et al., 1932). Failing excess base, salinity has been used on a few occasions.

It will be seen that the partial pressure showed no very large variation with depth. The changes at 5 metres have been plotted in Fig. 2. The partial pressure of carbon dioxide in the atmosphere is about $2.95 \times 10^{-4}$ atmospheres (Krümmel, 1907). For three months during the winter, the water column as a whole was in equilibrium with the atmosphere or very slightly supersaturated. With the onset of the spring plankton outburst, the partial pressure fell rapidly during March. Since the sea had become decidedly unsaturated with respect to free carbon dioxide, further fall due to photosynthesis was offset by solution from the atmosphere. The consumption of nutrient salts during April was not therefore accompanied by proportionate apparent consumption of carbon dioxide. That carbon dioxide was actually being used in quantity was shown by the rapid rise in oxygen.

The August gales with the resulting vertical mixing and surface turbulence resulted in a rise in partial pressure. During the autumn there was a trend upwards towards the winter maximum although this had not been reached when observations ceased.

Thus for nine months of the year the sea was unsaturated with regard to carbon dioxide which presumably it was dissolving from the atmosphere. During three winter months it was just saturated or slightly supersaturated. Since exchange of carbon dioxide with the atmosphere in either direction is probably greatly aided by stormy weather, a disturbed equilibrium is likely to be restored more rapidly in winter than in summer. Nevertheless, the period of unsaturation was much longer and the degree of unsaturation was greater than the period and degree of supersaturation (if any) during winter.

\section{Total Carbon Dioxide.}

The total carbon dioxide, $\Sigma \mathrm{CO}_{2}$, in sea-water is the sum of the concentrations existing as $\mathrm{CO}_{2}\left(\right.$ or $\left.\mathrm{H}_{2} \mathrm{CO}_{3}\right)$ and as bicarbonate and carbonate ions. The results in Tables I to III are reduced to normal temperature and pressure. The average $\mathrm{CO}_{2}$ contents of the water column have been calculated by the method described in Part I, p. 722. The maximum for the year was reached in January and February when the partial pressure was also at a maximum. At L4 and El a fall due to consumption by plankton followed, and the minimum was reached by July or August. 


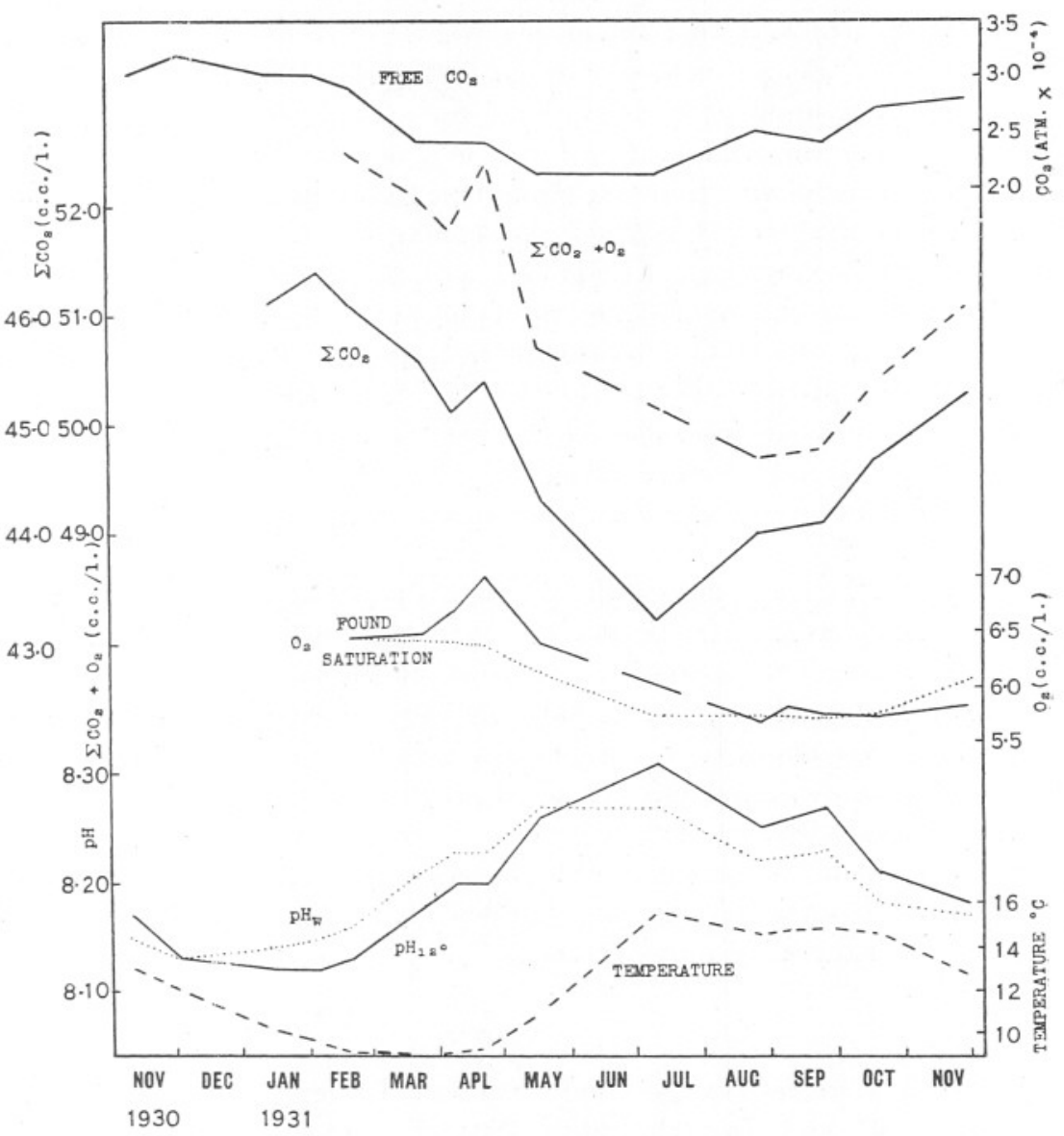

FIG. 2.- $\mathrm{CO}_{2}-\mathrm{O}_{2}$ system at Station El. November, 1930-November, 1931. Depth 5 metres, except November-February for which surface values only are available.

(1) $\mathrm{CO}_{2}$ partial pressure.

(2a) Oxygen found.

(2b) Volume of oxygen required to saturate the water at the temperature in situ. under one atmosphere pressure.

(3) Total ( $\Sigma$ ) carbon dioxide dissolved in the water.

(4) Sum of total volumes of carbon dioxide and oxygen.

(5a) $\mathrm{pH}$ of the water at the temperature of collection.

(5b) $\mathrm{pH}$ of the water if the temperature is changed to $12^{\circ} \mathrm{C}$. without gain or loss. of $\mathrm{CO}_{2}$.

(6) Temperature, ${ }^{\circ} \mathrm{C}$. 
The figures do not show a straightforward relationship with nutrient salts since, between April 7th and 22nd, when these all showed heavy consumption, total carbon dioxide showed no great change. From then onward there was a much more rapid fall, particularly above the thermocline, even between mid-May and early July when nutrient salts remained very low. The values for $\Sigma \mathrm{CO}_{2}$ at 5 metres at E1 in Fig. 2 may be compared with those for the nutrient salts in Part I, Fig. 8.

At Station E2 in early February both total carbon dioxide and partial pressure were lower than at E1, agreeing with the earlier start of the spring outbreak in mid-Channel deduced from phosphate data. Nevertheless, in the succeeding two months total carbon dioxide fell by $1 \cdot 1$ c.c. per litre at E1 compared with only 0.5 c.c. at E2. This again agrees with the deductions from nutrient salts that the early start at E2 was not followed up so effectively as the later start at E1.

In the autumn total carbon dioxide increased towards the winter maximum.

The daily change in carbon dioxide throughout the year is graphed in Fig. 14 in Part I. The results are there expressed in terms of the microgram-atom ( $10^{-6}$ gram-atom) of carbon for comparison with the data for phosphorus, silicon, and nitrate-nitrogen. Between mid-May and early July consumption of carbon was very marked, yet during this period phosphate and nitrate remained practically exhausted.

Since the total seasonal change in $\Sigma \mathrm{CO}_{2}$ represents only about $3 \%$ of the whole, its measurement affords a less accurate criterion of changes in the sea than do determinations of phosphate and nitrate, for which the percentage changes are much greater.

\section{Oxygen.}

Determinations of oxygen were made only for E1 and between February 19th and November 30th, 1931. Weather did not permit of the preparation of oxygen samples on board on July 10th. The resulting lack of data between May 18th and August 26th is unfortunate. During the height of the plankton outburst oxygen increased rapidly, reaching $8 \%$ supersaturation at the surface on April 22nd (cf. Fig. $2 ; 5$ m.). During May, with rising temperature, the degree of supersaturation fell. Examination of the data for $\Sigma \mathrm{CO}_{2}+\mathrm{O}_{2}$ below shows that this was mainly due to loss of oxygen to the atmosphere.

\section{Loss of Oxygen to the Atmosphere.}

The measurements of oxygen alone record a loss of 1.35 c.c. per litre between April 22nd and August 26th. During most of this period the surface of the sea was supersaturated with respect to oxygen. Since the 
figure is affected by the balance between photosynthesis and respiration it gives but a rough guide to the real loss to the atmosphere. But the photosynthesis

reactions $\mathrm{CO}_{2} \rightleftharpoons \mathrm{O}_{2}$ involve no change in the sum of the respiration

two gases, $\Sigma \mathrm{CO}_{2}+\mathrm{O}_{2}$.

Between February 19th and August 26th the partial pressure of carbon dioxide in the surface of the sea was always less than that in the atmosphere. In spite of this the sea suffered a loss of $\Sigma \mathrm{CO}_{2}+\mathrm{O}_{2}$, particularly during May and June. This loss $(2 \cdot 5$ c.c. per litre from the whole water column) may be attributed to loss of oxygen to the atmosphere and to removal of carbon dioxide as calcium carbonate by plants and by deposition. From the small variation in excess base it has been possible to arrive at a rough measure of the amount of calcium and consequently of carbon dioxide removed during the summer to form calcium carbonate in the various possible ways. The biggest observed difference at the surface in the ratio $\frac{\text { excess base }}{\text { chlorinity }}$ during the year was between February 19th and September 8th (see Section VII). It amounted to $8 \times 10^{-4}$, when excess base is expressed as milli-equivs. per litre and $\mathrm{Cl}$. as \% \% . From this the loss of $\mathrm{CO}_{2}$ as $\mathrm{CaCO}_{3}$ is $0 \cdot 18$ c.c. per litre. Since the figure depends on a difference in the third place of the measurement of excess base, it is very approximate, is probably maximal, and shows little more than the order of magnitude of the effect. Nevertheless, it is small compared with the loss of $\Sigma \mathrm{CO}_{2}+\mathrm{O}_{2}$. If the figure for the latter, 2.5 c.c per litre, is corrected for the loss as $\mathrm{CaCO}_{3}, 2 \cdot 3$ c.c. per litre remains as the net loss due to evasion of oxygen to the atmosphere during the course of the summer. This amounts to 161 litres from a column, 1 sq.-metre cross section and 70 metres deep. This loss of oxygen is greater than that due to rise of temperature alone. Between the dates of minimum and maximum temperatures at the surface or maximum and minimum oxygen saturation values, 0.75 c.c. per litre could have been lost from the surface layers, due solely to rising temperature. From this a maximum figure may be calculated for the whole water column on the assumption that all the excess oxygen was able to come to the surface and pass into the atmosphere. It is 52.5 litres per sq. metre $\times 70$ metres. It would seem too large since vertical mixing of the water column was hindered by the thermocline and diffusion in a liquid is an exceedingly slow process. But even so, at least $(161-52 \cdot 5)=$ say, 110 litres per sq. metre $\times 70$ metres of the oxygen given off to the atmosphere, was the product of photosynthesis.

Taking the figures for the area and average depth of the Channel given NEW SERIES.-VOL. XVIII. NO. 2. JANUARY, 1933. 
on p. 744, this is equivalent to the liberation of 9 cubic kilometres of oxygen due to photosynthetic activity in the whole of the Channel.

If events in the Channel can be regarded as occurring in a closed cycle, the carbon dioxide in the sea should be maintained by solution from the atmosphere, i.e. the water of the English Channel was able to replace 9 cubic kilometres of carbon dioxide by an equal volume of oxygen. This is the total volume of carbon dioxide in 30,000 cubic kilometres of air. Stated in another form, it implies that the sea, in effect, had removed the entire $\mathrm{CO}_{2}$ content of a stratum of air 370 metres in thickness.

These quantities of oxygen and carbon dioxide involve large transfers of gases across the surface of the sea to and from the atmosphere. Application of the evasion coefficient of $\mathrm{C}$. Bohr for oxygen and of the laboratory results of Adeney and collaborators (1918 et seq.) for the rate of absorption of oxygen by sea-water, show that the loss of oxygen can be easily accounted for. For carbon dioxide, however, the case is quite otherwise.

According to the invasion coefficient of Bohr (quoted by Krogh, 1904), the total volume of carbon dioxide invaded,

$$
V=\gamma\left(P_{a}-P_{w}\right) t \text { c.c. per sq. cm. of surface, }
$$

where $\quad \gamma=$ invasion coefficient

$P_{a}=$ partial pressure of $\mathrm{CO}_{2}$ in the atmosphere

$P_{v}=\quad, \quad, \quad, \quad, \quad, \quad$ surface of the sea

$t=$ time in minutes

$\gamma$ for $\mathrm{CO}_{2}=0 \cdot 1$ (Bohr, cited by Krogh, 1904).

$\mathrm{P}_{a}$ has been taken as $2.95 \times 10^{-4}$ atmosphere.

In Fig. 2, the partial pressure in the 5-metre layer is plotted against time. A similar curve may be plotted for the surface. The area between this curve and a horizontal at $2.95 \times 10^{-4}$ atmospheres (the partial pressure in the atmosphere, $\left.P_{a}\right)$, is a measure of $\left(P_{a}-P_{w}\right) t$ in (atmospheres $\left.\times 10^{-4}\right)$ days. Between February 19th and November 30th, 1931, it amounted to 151.5 (atmospheres $\times 10^{-4}$ )-days or 21.8 atmosphere-minutes. (1440 minutes $=1$ day.) This value may be substituted for $\left(P_{a}-P_{w}\right) t$ in the above invasion equation.

$\therefore V=0 \cdot 1 \times 21 \cdot 8=2 \cdot 18$ c.c. per sq. cm.,

or, say, 22 litres per sq. metre between the dates noted.

Since the sea-water is buffered with regard to $\mathrm{CO}_{2}$, a fairly large amount of $\mathrm{CO}_{2}$ may be absorbed without greatly altering the partial pressure in the surface water. But even so, and granting the applicability of the Bohr invasion coefficient and formula to the present problem, the figure, 22 litres per sq. metre, would seem to represent the maximum possible absorption. The presence of a fair amount of carbonate should not effect the initial solution of carbon dioxide which is primarily a physical transfer across the surface layer. That this is the case is supported by the work 
of Williamson and Mathews (1924) who found that the rate of absorption of carbon dioxide by distilled water and by solutions of potassium carbonate was dependent only on the partial pressure of the gas in the two phases and of course on the type of apparatus.

In the autumn as the water cools, oxygen will be redissolved, but this may be set off against the loss of oxygen with rising temperature in the early summer which was allowed for above.

The net result is that the amount of carbon dioxide which it would seem necessary for the sea to absorb from the atmosphere to make up for the amount converted to oxygen during photosynthesis, is six times as great as the invasion coefficient permits. But it must be remembered that, during rough weather with much churning and frothing of the surface water, the effective area of contact between air and water will be very much increased. Conditions will be very different from those of a laboratory experiment.

From another point of view also the result appears strange, for the conversion, year after year, of carbon dioxide to oxygen would lead to accumulation in the sea of organic material, which does not appear to be the case. Some other influence must therefore be at work. Since the summer of 1931 was unusually stormy in the Channel, it may have been characterised by unusually great loss of oxygen to the air from the disturbed waters. Again, there is a definite although slow drift up-Channel of water having its ultimate origin in the Atlantic, so that it may not be permissible to treat of events as occurring in a closed system. But after making all allowances, the order of magnitude of the oxygen loss in 1931 remains much the same.

\section{Calculation of the Plankton Crop from Chemical Data.}

Atkins (1922) has measured the plankton crop off Plymouth from the change in $\mathrm{CO}_{2}$ as measured by a titration method and also from change in phosphate. From the data for carbon dioxide, oxygen, phosphate, nitrate, and silicate collected in 1931, the author has made further estimates of the plankton production.

\section{(1) From change in carbon dioxide.}

The depth at Station L4 is about 53 metres, at E1 72 metres, and at E2 90 metres. The average depth of the Channel, determined from an Admiralty chart, between lines drawn from Dover to Cap Grisnez on the east and Land's End to Ushant on the west is about 72 metres.

The fall in carbon dioxide, determined from $\mathrm{pH}$ and excess base, has been measured between the winter maximum and the summer minimum. The subsequent calculation has been made as by Atkins (1922) ; $2 \cdot 226$ c.c. of $\mathrm{CO}_{2}$ is equivalent to $4.4 \mathrm{mg}$. $\mathrm{CO}_{2}, 1 \cdot 2 \mathrm{mg}$. carbon or $3.0 \mathrm{mg}$. dextrose 
or other hexose. Atkins used the assumption that the carbohydrates of the algal cell, including protein carbon, amount to $15 \%$ of the wet weight.

$\begin{array}{cccccc}\text { Station. } & \text { Between } & \begin{array}{c}\text { Fall in } \\ \mathrm{CO}_{2} \\ \text { c.c./1. }\end{array} & \begin{array}{c}\text { Dextrose } \\ \text { formed } \\ \text { mg./1. }\end{array} & \begin{array}{c}\text { g. } / \mathrm{m}^{3} \text {. } \\ \text { Letric tons per sq. km. } \\ \text { of surface calculated } \\ \text { on a mean depth } \\ \text { of } 72 \mathrm{~m} .\end{array} \\ \text { E1 } & 19 / 2-10 / 7 & 2 \cdot 4 & 3 \cdot 24 & 21 \cdot 6 & 1,550 \\ \text { E2 } & , " & 2 \cdot 7 & 3 \cdot 63 & 24 \cdot 2 & 1,730 \\ \text { Mean } & 4 / 2-26 / 8 & 1 \cdot 8 & 2 \cdot 43 & 16 \cdot 2 & (1,160) \\ & & & & & 1,640\end{array}$

Since for E2 only quarterly data are available, it has been ignored in calculating all means. The figures are minimal since an increase in $\mathrm{CO}_{2}$ will occur, due to respiration of plants and animals, and the gas will be dissolved from the atmosphere during the period under consideration.

(2) From oxygen lost to the atmosphere.

It was found above that in the course of the spring and summer, at least 110 litres of oxygen was given off from a column 1 sq. metre in cross section and 70 metres deep. This was formed from an equal volume of carbon dioxide so that by similar reasoning to the above the following calculation may be made :Phytoplankton formed, wet weight. Loss of $\mathrm{O}_{2}$
litres per Dextrose

Station. Between sq. m. $\times 70 \mathrm{~m}$. sq. m. $\times 70 \mathrm{~m}$.

Metric tons per sq. $\mathrm{km}$. of surface calculated

E1

$$
19 / 2-26 / 8
$$

110

150 on a mean depth of $72 \mathrm{~m}$.

This figure is certainly too small since much of the oxygen set free by photosynthesis will be quickly re-utilised in respiration. Although based on different data, this result is not independent of (1) since certain steps in the argument are common to both.

\section{(3) From consumption of phosphate.}

Atkins (1923, p. 140) calculated the plankton crop from the seasonal fall in phosphate. On a similar basis the writer has arrived at the following results for 1931 :

\begin{tabular}{ccccc} 
Station. & Between & $\begin{array}{c}\text { Fall in } \\
\mathrm{P}_{2} \mathrm{O}_{5} \\
\mathrm{mg} \cdot / \mathrm{m}^{3} .\end{array}$ & \multicolumn{2}{c}{$\begin{array}{c}\text { Phytoplankton formed, wet weight. } \\
\text { Metric tons per sq. km. of } \\
\text { surface calculated on } \\
\text { a mean depth of } 72 \mathrm{~m} .\end{array}$} \\
L4 & $19 / 2-10 / 7$ & 22 & $14 \cdot 8$ & 1,070 \\
E1 & $4 / 12-26 / 8$ & $26 \cdot 3$ & $17 \cdot 6$ & 1,260 \\
E2 & $4 / 2-26 / 8$ & $19 \cdot 9$ & $13 \cdot 2$ & $\underline{(950)}$ \\
Mean & & & & 1,170
\end{tabular}




\section{(4) From consumption of nitrate.}

In order to calculate the plankton crop from the consumption of nitrate, it is necessary to know the amount of nitrogen in a given wet weight of plankton. Suitable figures are available in "Fertilizer Resources of the United States" (U.S. Senate Document, No. 190), pp. 223-231.

As a mean of a number of analyses by Barlow, by Russell and by Tom of a number of British seaweeds, collected at different places and at different seasons, nitrogen constitutes about $2 \%$ of the dry weight. The dry weight is about $24 \cdot 2 \%$ of the wet weight. This figure is based on Tom's results and was used in the above phosphate calculation. The nitrogen therefore constitutes about $0.5 \%$ of the wet weight of algæ. The extension of the result to the plankton seems admissible, so that from the known consumption of nitrate-nitrogen the minimum crop production may be calculated :-

\begin{tabular}{|c|c|c|c|c|}
\hline Station. & Between & $\begin{array}{l}\text { Fall in N } \\
\mathrm{mg} \cdot / \mathrm{m}^{3} .\end{array}$ & g. $/ \mathrm{m}^{3}$. & $\begin{array}{l}\text { Metric tons per sq. km. of } \\
\text { surface calculated on a } \\
\text { mean depth of } 72 \mathrm{~m} .\end{array}$ \\
\hline L4 & $4 / 12-10 / 7$ & 116 & $23 \cdot 2$ & 1,670 \\
\hline E1 & $23 / 3-10 / 7$ & 88 & $17 \cdot 6$ & 1,270 \\
\hline $\mathrm{E} 2$ & $4 / 2-26 / 8$ & 39 & $7 \cdot 8$ & $(570)$ \\
\hline
\end{tabular}

Mean

1,470

(5) From consumption of silicate.

Wailes (1929) states that half a dozen nearly pure gatherings of plankton. diatoms, mostly small species of Chrtoceros, collected in Departure Bay, Vancouver Island, and dried for one hour at $110^{\circ} \mathrm{C}$., contained on an average $40 \%$ of silica. Gatherings mostly composed of Coscinodiscus gave a percentage around $55 \%$. When dried until there was no further loss of weight, the percentage of silica was about $75 \%$. If the wet weight is taken as four times the dry weight, silica thus constitutes approximately $13 \%$ of the wet weight. The following calculation may therefore be made :-

$\begin{array}{ccccc}\text { Station. } & \text { Between } & \begin{array}{c}\text { Fall in } \\ \mathrm{SiO}_{2} \\ \mathrm{mg} \cdot \mathrm{m}^{3} .\end{array} & \begin{array}{r}\text { Phytoplankton formed, wet weight. } \\ \text { Metric tons per sq. km. of } \\ \text { surface calculated on a } \\ \text { mean depth of } 72 \mathrm{~m} .\end{array} \\ \text { L4 } & 19 / 2-18 / 5 & 200 & 1 \cdot 54 & 110 \\ \text { E1 } & 13 / 1-18 / 5 & 208 & 1 \cdot 60 & 115\end{array}$

Mean 
The minimum production calculated in these five ways may be summarised :-

Basis.
$\mathrm{CO}_{2}$
$\mathrm{O}_{2}$
Phosphate
Nitrate.
Silicate.

Minimum production of phytoplankton wet weight, metric tons per sq. $\mathrm{km}$.

The agreement between the first four of these figures is striking. The earlier calculations of Atkins gave 1,400 metric tons per sq. km., both from titration $\mathrm{CO}_{2}$ and from phosphate. All the figures are minima and would be increased by the substances taking part in the life-cycle more than once. No exact figures for the proportion of siliceous diatoms to the total phytoplankton in 1931 are available. The above results, at first sight, point to the proportion being one-tenth or less. This is highly improbable, so that alternatively silica would seem to go through the life-cycle several times in one season. This is quite likely.

No such high concentration of plankton as here calculated is actually found at the end of the spring outburst. Some of it dies off and much of it is eaten by animals. Organic material, phosphorus and nitrogen are all required by the animals for their own purposes, and so for the time being are removed from the sea-water. But inasmuch as the animal organism requires little silica, almost the whole of it would be excreted at once. The speed with which silica can redissolve in sea-water is still a moot point, but the evidence presented in Part I, Section IV, points to re-solution being quite rapid. If then the excreted silica can be rapidly redissolved and made available for a second growth-cycle, the above low apparent crop production is explained as well as the fact that silicate in the sea is seldom found completely exhausted and functioning as a limiting factor in diatom growth.

A representative figure for the minimum phytoplankton production in the Channel would seem to be 1,400 metric tons per sq. kilometre for an area 72 metres deep. This is the average depth of the whole Channel. Its area is about $82,100 \mathrm{sq}$. kilometres. The minimum production for the whole area is therefore 115 million metric tons. It is interesting to compare this with the total landing of commercial fish from the English Channel at English and French ports during 1928 (Conseil International p. l'Expl. de la mer. Bull. Statistique des pêches maritimes, XVIII, p. 49). The amount was 71,000 metric tons. This figure seems suitable for the present purpose. Thus,

$$
\frac{\text { Fish landed }}{\text { Phytoplankton produced }}=\frac{71,000}{115,000,000}=0 \cdot 0006
$$


Thus, only $0 \cdot 06 \%$ of the phytoplankton produced each year is harvested as fish for the use of man and this in a region where the fishing has become so intense that many large English steam trawlers now find it unprofitable.

\section{Variation in Excess Base with Depth.}

The most appropriate function to consider is $\frac{\text { Excess Base }}{\text { Chlorinity }}=\frac{\mathrm{A}}{\mathrm{Cl}}$. It will be seen from Table IV that the observed variations are small. The year has been divided into two parts, viz. (a) Winter, including determinations made between January 1st and April 15th and between October 10th and November 30th (6 cruises) and $(b)$ Summer, including determinations made between April 16th and October 9 th (6 cruises). During the winter vertical mixing is usually thorough. In the summer period, by contrast, the warmer surface water makes the water layers much more stable, so that a differential distribution is more likely to persist for a considerable time.

In Table $\mathrm{V}$ arithmetic means are calculated for each station and depth. When duplicate determinations of the excess base in the same sample exist, these have been treated as distinct. In the winter there was no difference between surface and bottom, but in the summer the arithmetic means showed a positive gradient downwards. The differences are admittedly small, but seem to be real, particularly as similar independent trends are shown by all four stations investigated.

The results have been examined statistically. Each group has been treated as measures of one quantity. The standard error, $\sigma_{m}=\sqrt{\frac{\Sigma d_{n}{ }^{2}}{n(n-1)}}$ calculated from the observed deviations $\left(d_{1}, d_{2}, \ldots d_{n}\right)$ from the mean, therefore incorporates experimental errors in the determination of excess base and of chlorinity and also any seasonal changes of whatever nature. For statistical purposes the distribution about the mean should be approximately normal, but this is by no means always the case. The standard error is given in each case where the number of data warrants. The observed differences between different pairs of depths are given in Table VI together with the standard error, $\sigma_{\mathrm{m}_{\mathrm{a}-\mathrm{b}}}=\sqrt{\sigma_{\mathrm{m}_{\mathrm{a}}}+\sigma^{2}{ }_{\mathrm{m}_{\mathrm{b}}}}$.

In summer at L4 and E1 the differences are as much as four times the standard error and are in the same direction. The quarterly results for E2 and the early autumn results for L6 agree very well with the more frequent determinations at L4 and E1. Some of the biggest deviations from the mean for the bottom samples (Table VII) occur in the early autumn, and it would seem very likely that these are real since regeneration and re-solution processes are very active at this season (cf. Part I). 
TABLE IV. $\frac{\text { ExCESS BASE (MILli-EQUiv. PER L.) } \times 10^{4}}{\text { ChLORINITY }(\%)}=\frac{\mathrm{A}}{\mathrm{Cl}} \times 10^{4}$

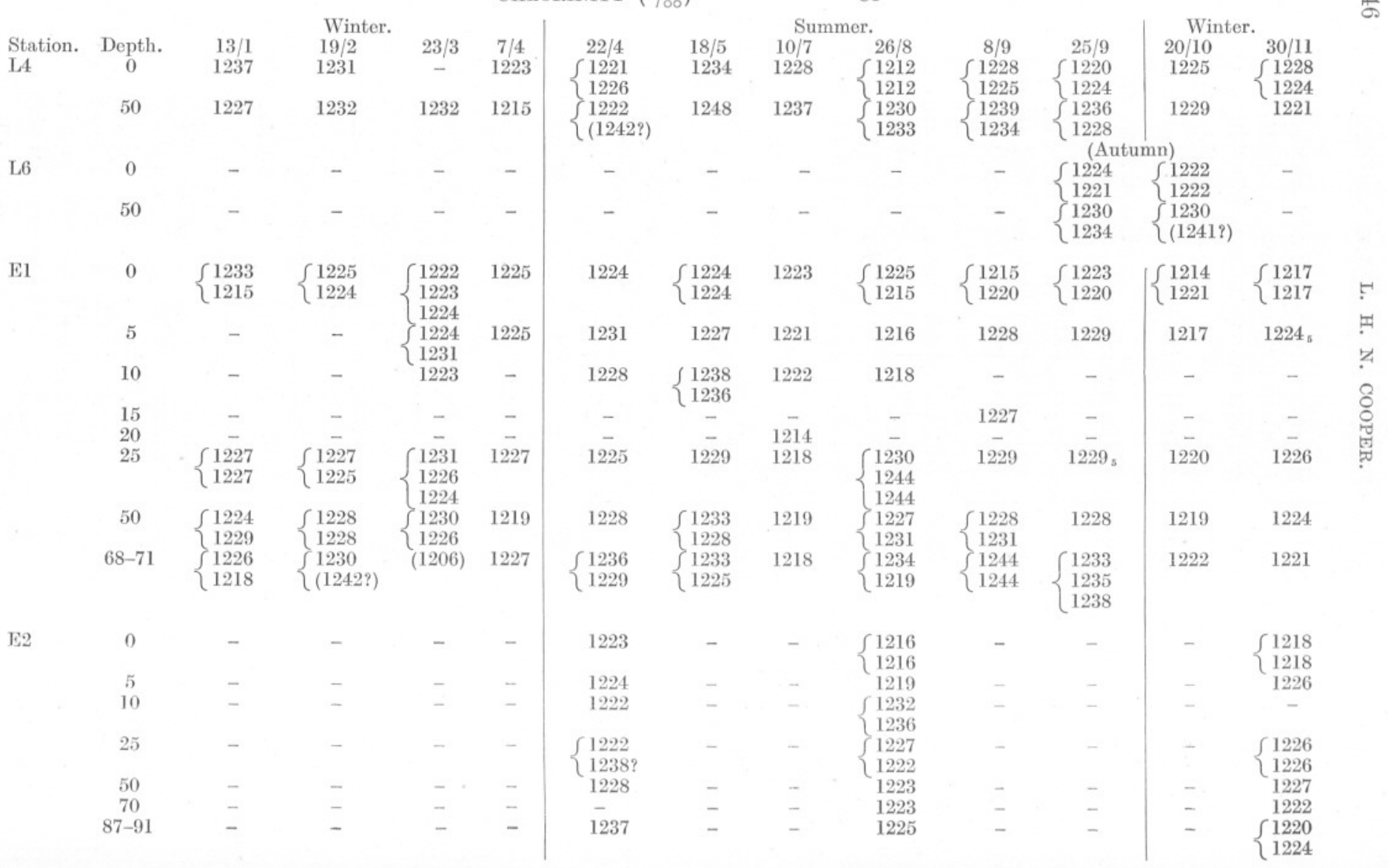


TABLE $V$.

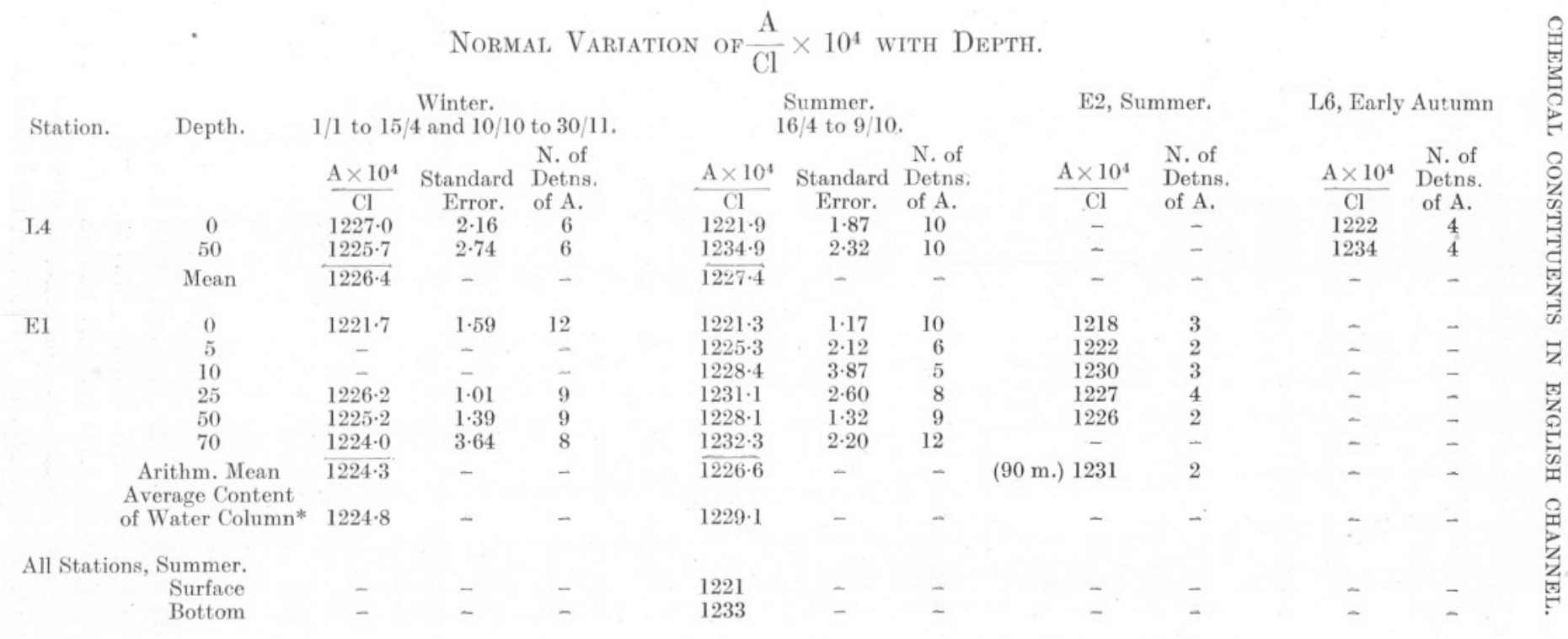

* For an explanation of this term, see p. 722 . 
In the statistical treatment these fluctuations have been treated as random errors, so that the standard error is increased and the normal form of distribution is upset.

\section{TABLE VI.}

\section{Variation in Excess Base with Depth.}

A positive difference means a greater value at the lower depth.

$$
B \text { means bottom depth. }
$$

\begin{tabular}{|c|c|c|c|c|}
\hline & & $\begin{array}{c}\text { Depths } \\
\text { Compared }\end{array}$ & $\begin{array}{l}\text { Observed Differences } \\
\text { and Standard Errors } \\
\qquad \mathrm{A} \times 10^{4}\end{array}$ & \\
\hline Season. & Station. & (in m.). & $\mathrm{Cl}$ & Significance. \\
\hline Winter & $\mathrm{L} 4$ & 0 and $50(\mathrm{~B})$ & $-1 \cdot 3 \pm 3 \cdot 49$ & Not significant \\
\hline, & E1 & 0 and $70(\mathrm{~B})$ & $+1.23 \pm 3.97$ & , \\
\hline Summer & L4 & 0 and $50(\mathrm{~B})$ & $+13 \cdot 0 \pm 3 \cdot 0$ & Significant \\
\hline , & E1 & 0 and $70(B)$ & $+11 \cdot 0 \pm 2.50$ & , \\
\hline , &, & 0 and 50 & $+6.8 \pm 1.76$ & , \\
\hline
\end{tabular}

Stations not admitting statistical treatment :-

$\begin{array}{llll}\text { Summer } & \text { E2 } & 0 \text { and } 90(\mathrm{~B}) & +13 \\ \text { Early Autumn } & \text { L6 } & 0 \text { and } 65(\mathrm{~B}) & +12\end{array}$

\section{TABLE VII.}

\begin{tabular}{|c|c|c|c|c|c|c|c|c|c|}
\hline \multirow{4}{*}{$\begin{array}{l}\text { Station } \\
\text { Date }\end{array}$} & $\begin{array}{l}\text { Depth } \\
\text { in } \mathrm{m} .\end{array}$ & \multicolumn{2}{|c|}{ El } & \multicolumn{3}{|c|}{$\begin{array}{l}\text { Depth } \\
\text { in } \mathrm{m} .\end{array}$} & $\begin{array}{l}\text { Depth } \\
\text { in } \mathrm{m} .\end{array}$ & \multicolumn{2}{|c|}{ L6 } \\
\hline & & $8 / 9$ & $25 / 9$ & & & $25 / 9$ & & $25 / 9$ & $20 / 10$ \\
\hline & 25 & 1229 & 1229 & 0 & 1226 & 1222 & 0 & 1222 & 1222 \\
\hline & 50 & 1229 & 1228 & & & & & & \\
\hline & 68 or 70 & 1244 & 1235 & 50 & 1237 & 1232 & 62 or 67 & 1232 & 1230 \\
\hline $\begin{array}{l}\text { ound- } \\
\text { ing }\end{array}$ & 70 or 73 & & & 53 & & & & & \\
\hline
\end{tabular}

\section{TABLE VIII.}

\section{Variation of Calcium with Depth in Summer.}

\begin{tabular}{|c|c|}
\hline Station. & $\begin{array}{c}\text { Excess of calcium } \\
\text { at bottom over surface } \\
\text { (with } \mathrm{Standard} \text { Error) } \\
\mathrm{mg} . \mathrm{Ca} / \mathrm{m}^{3} \text {. }\end{array}$ \\
\hline L4 & $+500 \pm 115$ \\
\hline E1 & $+425 \pm 95$ \\
\hline Mean & $+460 \pm 105$ \\
\hline
\end{tabular}

Wattenberg (1930), on the basis of work in the Atlantic, concluded that removal and solution of $\mathrm{CaCO}_{3}$ was the principal cause of fluctuations in excess base. If this was the case in the English Channel, the data of Table VI may be converted to show variation of calcium content in summer with depth. Table VIII shows such data calculated 
for $35 \cdot 05 \%$ S. $(19 \cdot 40 \%$ Cl.). The average difference between the surface and bottom waters of the Channel off Plymouth in the summer of 1931 was about $460 \pm 110 \mathrm{mg}$. Ca per cubic metre. On September 8 th the difference between the calcium content of the $50 \mathrm{~m}$. and $70 \mathrm{~m}$. (bottom) layer may have been as great as $600 \mathrm{mg} . \mathrm{m}^{3}$. On this date phosphate, silicate, and nitrite all showed quite marked increases towards the bottom although salinity and temperature changed little, so that regeneration of phosphate, silicate, nitrogen, and calcium seem to have been proceeding simultaneously at the bottom.

\section{TABLE IX.}

September 8th, 1931. Station E1. (All in MG./M³.)

\begin{tabular}{lrrrc}
\multicolumn{1}{c}{ Depth in m. } & $\mathrm{P}_{2} \mathrm{O}_{5}$ & $\mathrm{SiO}_{2}$ & Nitrite $\mathrm{N}$ & $\mathrm{Ca}$ \\
50 & $9 \cdot 5$ & 165 & $3 \cdot 6\}$ & - \\
70 (bottom) & $13 \cdot 5$ & 220 & $9 \cdot 85$ & +600 (v. approx.) \\
Difference & +4 & +55 & $+6 \cdot 2$ & +60
\end{tabular}

When compared with the total calcium content of sea-water of $35 \%$ salinity (about $4.2 \times 10^{5} \mathrm{mg} . / \mathrm{m}^{3}$ ) the percentage variation between surface and bottom in summer amounts to $(0 \cdot 11 \pm 0 \cdot 03) \%$.

The statistical treatment lends support to the conclusion, but it should be remembered that the number of analyses was small and the dispersion about the means was greater than was desirable. Nevertheless, it is felt that the agreement between the results for the different stations affords fairly strong evidence in favour of a slight increase in excess base between the surface and bottom in the English Channel in summer, equivalent to $0 \cdot 1 \%$ of the total calcium content. To establish the conclusion with absolute certainty requires further work. The author is indebted to $\mathrm{Mr}$. J. A. Harris, of Christ's College, Cambridge, for assistance in the statistical analysis of the results.

\section{Methods.}

Concentration of Hydrogen Ion. Measurements of $\mathrm{pH}$ have been made colorimetrically with McClendon (1917) boric-borate buffers as described by Atkins (1923, Part II). In genera], cresol red has been used as indicator with thymol blue and xylenol blue for confirmatory determinations over the more alkaline range. Since the buffers contain the appropriate amount of sodium chloride, salt error is automatically corrected for when salinity is near to $35 \cdot 2 \%$. Samples have been preserved on collection with mercuric chloride (4 drops of saturated solution per 170 c.c.) and brought to the Laboratory in the standard dark green bottles, full or with but a small air space over the water. The $\mathrm{pH}$ was commonly determined 
the same night or occasionally on the following morning. Under these conditions Ibañez (1931) has shown that there is little or no change in the $\mathrm{CO}_{2}$ content of the water.

The temperature of the Laboratory is usually higher than that of the sea. Buch (1929, 1 and 2) has shown that when loss or gain of $\mathrm{CO}_{2}$ is precluded :-

$$
\text { where } \begin{aligned}
\mathrm{pH}_{\mathrm{w}} & =\mathrm{pH}_{\mathrm{b}}+\alpha\left(\mathrm{t}_{\mathrm{b}}-\mathrm{t}_{\mathrm{w}}\right)+\beta\left(\mathrm{t}_{\mathrm{w}}^{\prime}-\mathrm{t}_{\mathrm{w}}\right) \\
\mathrm{t}_{\mathrm{w}} & =\text { temperature of water on collection } \\
\mathrm{t}_{\mathrm{w}}^{\prime} & =\quad, \quad \text { when compared } \\
\mathrm{t}_{\mathrm{b}} & =\quad, \quad \text { buffer , " }, \\
\mathrm{pH}_{\mathrm{w}} & =\mathrm{pH} \text { of water at temperature } \mathrm{t}_{\mathrm{w}} \\
\mathrm{pH}_{\mathrm{b}} & =\mathrm{pH} \text { of buffer at temperature } \mathrm{t}_{\mathrm{b}} .
\end{aligned}
$$

In the present case $\mathrm{t}_{\mathrm{w}}^{\prime}=\mathrm{t}_{\mathrm{b}}=$ temperature of the Laboratory

$$
\therefore \quad \mathrm{pH}_{\mathrm{w}}=\mathrm{pH}_{\mathrm{b}}+(\alpha+\beta)\left(\mathrm{t}_{\mathrm{b}}-\mathrm{t}_{\mathrm{w}}\right)
$$

i.e. a positive correction factor must be applied when the temperature of the Laboratory is above that of the sea.

When cresol red is used $(\alpha+\beta)=+0 \cdot 011$.

This correction, which is based on an extensive spectrophotometric and electrometric examination, is in the opposite direction to that of McClendon (1917), which is for carbon dioxide equilibrium at the temperature of the water. In Tables I to III, the values of $\mathrm{pH}$ observed at the temperature of the Laboratory have been corrected by the Buch factor to the $\mathrm{pH}$ at the temperature of collection.

The value, $\mathrm{pH}_{\mathrm{w}}$, has a real physical meaning since it is the actual $\mathrm{pH}$ of the water in the sea. Since the interpolation tables of Buch, Harvey, Wattenberg, and Gripenberg (1932) take account of temperature, it is most suitable for calculation of the partial pressure and total amount of carbon dioxide.

But comparison of the $\mathrm{pH}$ values amongst themselves can only be made if all readings are corrected to a standard temperature. The temperature, $12^{\circ}$, is convenient since it is roughly the middle point of the annual range. The true $\mathrm{pH}$ of sea-water decreases by 0.011 unit for a rise of temperature of $1^{\circ} \mathrm{C}$.

Chlorinity and excess base, which also affect $\mathrm{pH}$, may, for this purpose, be taken as practically constant at Station E1. At L4, however, there may be a small error involved. The figures for $\mathrm{pH}_{12}{ }^{\circ}$ are intended to show variations due to biological activity and exchange of $\mathrm{CO}_{2}$ with the atmosphere independently of temperature changes.

In a private communication received since this paper went to press, Buch and Gripenberg suggest that the following temperature corrections should be applied :-

(1) The Walbum correction, if the buffers do not have the same 
temperature as that at which they were calibrated (positive if $t_{\text {calibr. }}>t_{b}$ ) (Buch, 1929, (2)).

(2) Correction $\alpha$ to correct for indicator displacement if the water and the buffers have different temperatures (positive if $t_{b}>t^{\prime}{ }_{w}$ ).

(3) Correction 0.011 if the $\mathrm{pH}$ of the water at any other temperature (e.g. in situ or at $12^{\circ}$ ) is wanted.

In the present case (2) does not apply. The third correction is equivalent to that actually made above. The Walbum correction (which was worked out for Sörensen's borate-HCl buffers) was not made. It probably applies also to McClendon's buffers. These were calibrated at $20^{\circ}$. To make the Walbum correction, the following factors must be added to the figures given in Tables I to III and the curves in Fig. 1 must be moved to the right by the same amount:-Nov. 11, 1930, to Feb. 19, 1931, April 22 and Nov. 30, 1931, 0.03 unit; April 7, May 18, Sept. 25 and Oct. 20, 0.02 unit; Mar. 23 and Aug. 26, 0.01 unit; and July 10, nil.

Oxygen has been determined by Winkler's method. No correction has been applied to compensate for the volume of sea-water displaced by the reagents without reaction therewith. If made it would increase all values by about 0.07 c.c. per litre. Fox's table (1907) has been used for calculating the saturation values at the temperature and salinity found at the surface on each occasion. Most of the results appear to be accurate to within \pm 0.03 c.c. 1 . But on one or two cruises, when working conditions on the ship were not of the best, considerably greater differences between duplicates were shown.

Excess base (Alkalinität) has been determined by Wattenberg's method (1930).

\section{SUMMARY.}

(1) In general, the changes in $\mathrm{pH}$ were similar to those observed in previous years. On six occasions the $\mathrm{pH}$ at the surface at Station L4 was lower than at the bottom.

(2) The changes in carbon dioxide in the spring agree with the conclusion, formed in Part I from nutrient salt data, that the early start in plant production in mid-Channel was not maintained and that by the middle of April production had become much greater nearer the shore.

(3) The partial pressure of $\mathrm{CO}_{2}$ during nine months out of twelve has been observed to be lower than that of the atmosphere and equal or slightly higher during the remaining three months.

(4) It is suggested that the fall in (Total $\left.\mathrm{CO}_{2}+\mathrm{O}_{2}\right)$ during the course of 
the summer was due mostly to loss of oxygen to the atmosphere. After allowing for carbon dioxide possibly removed from the sea as calcium carbonate and for the loss of oxygen due solely to rising temperature of the water, a net loss of 110 litres of oxygen was found from a column 1 sq. metre in cross-section and 70 metres deep; or 9 cubic kilometres from the whole of the Channel. If this is regarded as a closed system, the oxygen must have been formed during photosynthesis from an equal volume of $\mathrm{CO}_{2}$ dissolved from the atmosphere. But the required transfer of $\mathrm{CO}_{2}$ across the surface of the sea is too great to be accounted for by existing data on the rate of invasion of $\mathrm{CO}_{2}$ into sea-water as calculated for a small bubble of gas in water.

(5) Estimates of the phytoplankton crop have been made, based on the seasonal consumption of carbon dioxide, of phosphate and of nitrate and on the oxygen lost to the atmosphere. All four are of the order of 1,400 metric tons wet weight per sq. $\mathrm{km}$. of surface, in close agreement with the figure calculated by Atkins. The crop production calculated from consumption of silicate is less than one-tenth of this. This is attributed not only to the presence of planktonic organisms requiring no silica but to the silicate being used several times over in the course of the season.

(6) About $0.06 \%$ of the wet weight of phytoplankton produced is harvested as fish.

(7) A small variation in excess base, equivalent to about $0 \cdot 1 \%$ of the total calcium present, has been detected between the surface and bottom in summer. The result requires confirmation.

\section{REFERENCES.}

Adeney, W. E., and Becker, H. G. 1918-20. The Determination of the Rate of Solution of Atmospheric Nitrogen and Oxygen by Water. Parts I-III. Scient. Proc. Roy. Dublin Soc., Vol. 15, pp. 385-404, 609-628; Vol. 16, pp. 143-152.

Adeney, W. E., Leonard, A. G. G., and Richardson, A. 1922. On the Aeration of Quiescent Columns of Distilled Water and of Solutions of Sodium Chloride. Scient. Proc. Roy. Dublin Soc., Vol. 17, pp. $19-28$.

Adeney, W. E. 1926. On the Rate and Mechanism of Aeration of Water under Open Air Conditions. Scient. Proc. Roy. Dublin Soc., Vol. 18, pp. 211-217.

Atkins, W. R. G. 1922, '23, '24. The Hydrogen Ion Concentration of Sea-water in its Relation to Photosynthetic Changes. Parts I-III. Journ. Mar. Biol. Assoc., N.S., Vol. 12, pp. 717-771; Vol. 13, pp. $93-118,437-446$. 
Buch, K. 1928. Die pH-Bestimmung des Meerwassers. Havsforskningsinst. Skrift No. 53, pp. 30.

Buch, K. 1929 (1). Über den Einfluss der Temperatur auf die pHBestimmung des Meerwassers. Havsforskningsinst. Skrift No. 61, pp. 23.

Buch, K. 1929 (2). On the Determination of $\mathrm{pH}$ in Sea-water at Different Temperatures. Journ. du Conseil, Vol. 4, pp. 267-280.

Buch, K., Harvey, H. W., Wattenberg, H., and Gripenberg, S. 1932. Über das Kohlensäuresystem im Meerwasser. Conseil Int. p. l'Exploration de la Mer. Rapp. et Procès-verbaux, Vol. 79, pp. 70.

Fox, C. J. J. 1907. On the Coefficients of Absorption of the Atmospheric Gases in Sea-water and Distilled Water. Publ. de Circonstance, No. 41. Copenhagen.

IbaÑez, O. G. 1931. On the Colorimetric Determination of $\mathrm{pH}$ in Seawater. Journ. Mar. Biol. Assoc., N.S., Vol. 17, pp. 483-488.

Krogh, A. 1904. The Abnormal $\mathrm{CO}_{2}$-Percentage in the Air in Greenland and the General Relations between Atmospheric and Oceanic Carbonic Acid. Meddelelser om Grönland, Vol. 26, pp. 407-434; cf. idem, ibid., pp. 331-405.

Krümmel, O. Handbuch der Ozeanographie, Band I. Stuttgart, 1907, p. 315.

McClendon, J. F. 1917. The Standardisation of a New Colorimetric Method for the Determination of the Hydrogen Ion Concentration, $\mathrm{CO}_{2}$ Tension, and $\mathrm{CO}_{2}$ and $\mathrm{O}_{2}$ Content of Sea-water, etc. Journ. Biol. Chem., Vol. 30, pp. 265-288.

Walles. 1929. Plant Life in the Open Sea. Museum and Art Notes, Vancouver, Vol. 4, No. 1, p. 25.

Wattenberg, H. 1930. Über die Bestimmung der Alkalinität des Meerwassers. Über den Kalkgehalt des Ozeanwassers. I. Mitteilung. Ann. d. Hydrographie usw., Vol. 58, pp. 277-282.

Wattenberg, H. 1931. Über den Kalkgehalt des Ozeanwassers. II. Mitteilung: Die Verteilung im Atlantischen Ozean. Ann. d. Hydrographie usw., Vol. 59, pp. 273-277.

Williamson, R. V., and Mathews, J. H. 1924. Rate of Absorption and Equilibrium of Carbon Dioxide in Alkaline Solutions. Ind. Eng. Chem., Vol. 16, pp. 1157-61. 